\title{
The Firefly Genus Vesta in Taiwan (Coleoptera: Lampyridae)
}

\author{
Ming-Luen Jeng, ${ }^{1}$ Ping-Shih Yang, ${ }^{2}$ And Michael S. Engel ${ }^{1}$
}

\begin{abstract}
The species of the firefly genus Vesta occurring in Taiwan are revised. Three species are recognized: Vesta scutellonigra Olivier (nomen emendatum), V. impressicollis Fairmaire, and V. rufiventris (Motschulsky). Vesta chevrolatii var. scutello nigro Olivier is automatically emended to scutellonigra under ICZN rules. Okada described as a distinct species $V$. scutellonigra, employing the same name and material as Olivier, thereby automatically rendering his taxon a junior synonym (n. syn.). The name V. scutellonigro, simultaneously employed by Okada, is considered an incorrect subsequent spelling and therefore unavailable. Vesta formosana Pic (n. syn.) is a new junior synonym of $V$. scutellonigra. The spelling chevrolati, employed by Gemminger and Harold, is determined to be an incorrect subsequent spelling of chevrolatii and thus unavailable. Lectotypes are newly designated for $V$. scutellonigra Olivier, $V$. impressicollis Fairmaire, and $V$. formosana Pic. A key to the species of Taiwan is provided. Vesta flaviventris (Fairmaire) (n. comb.) from China is transferred from Lucernuta.

KEY WORDS: Vesta, Lampyridae, Taiwan, nomenclature, key
\end{abstract}

\section{Introduction}

Owing to the well-founded and careful work undertaken by earlier European and Japanese researchers, the taxonomy and faunal studies of Lampyridae occurring in Taiwan (Formosa) has been extensively improved during the past 100 years (Olivier, 1910b, 1911a, 1913; Pic, 1911a, 1911b, 1911c, 1916, 1917, 1918, 1944; Matsumura, 1918, 1928; Kano, 1930; Okada, 1931; Miwa, 1931; Nakane, 1967a, 1967b, 1977; Chûjô and Satô, 1970; Satô 1970; Ho, 1997; Ho and Jiang, 1997; Ho and Jong, 1997, Ho et al., 1998a, 1998b; Jeng et al., 1998a, 1998b, 1999a, 1999b, 1999c, 2000, 2001, 2002, 2003a, 2003b, 2003c; Lai et al., 1998; Chen, 1999, 2003; Chang et al., 2000; Ho and Chu, 2002). Some forty species belonging to nine genera (Curtos Motschulsky, Cyphonocerus Kiesenwetter, Diaphanes Motschulsky, Lamprigera Motschulsky, Lucidina Gorham, Luciola Laporte de Castelnau, Pristolycus Gorham, Pyrocoelia Gorham, and Vesta Laporte de Castelnau) were recorded from the island and its accessory islets. A further two genera, Drilaster Kiesenwetter and Stenocladius Fairmaire, containing ten known species from Taiwan and listed in the checklist of Lai et al. (1998), are now considered as doubtful as to their placement within Lampyridae (Branham and Wenzel, 2001).

The genus Vesta, based on $V$. chevrolatii Laporte de Castelnau from Java, is widespread in East and Southeast Asia as well as the Neotropical region (McDermott, 1966). Such a pattern of distribution is unique within the family Lampyridae. It is possible that many of the western species were erroneously transferred to (mostly from Ethra Laporte de Castelnau) or assigned to Vesta by

\footnotetext{
${ }^{1}$ Division of Entomology, Natural History Museum, and Department of Ecology \& Evolutionary Biology, 1501 Crestline Drive - Suite 140, University of Kansas, Lawrence, Kansas 66049-2811.

${ }^{2}$ Department of Entomology, National Taiwan University, \#1, Sec. 4, Roosevelt Road, Taipei 106, Taiwan. 
Olivier (1907) owing to their pectinate antennae, a feature today understood to be of little diagnostic value. A thorough revision of the genus is certainly needed.

In regard to the Taiwanese fauna, Olivier (1911a) recorded three species of VestaVesta chevrolatii, V. impressicollis Fairmaire, and V. rufiventris (Motschulsky) based on material collected by Hans Sauter in the early 20th Century. Later he described the Taiwanese population of $V$. chevrolatii as a variety under the name scutello nigro (Olivier, 1913). Subsequently, Kano (1930) redundantly recorded $V$. impressicollis as new to Taiwan, and these three species were cited by Miwa (1931) for Taiwan. Okada (1931) described the variety scutello nigro as a new species and named it $V$. scutellonigra Okada and $V$. scutellonigro Okada simultaneously. Pic (1944) described a putative fourth species, V. formosana, from southern Taiwan, the status of which is revised herein. Most recently, Lai et al. (1998) listed all of the aforementioned four species [except $V$. scutellonigra Okada] for the fauna of Taiwan. During examination of type collections for related species in the Muséum national d'Histoire naturelle, Paris (MNHN), we noted some taxonomic corrections needed for those species occurring in Taiwan. Accordingly, we herein present a revision of the Taiwanese fauna.

\section{Material and Methods}

Specimens were collected by the first author if not otherwise specified. Male genital segments were dissected for examination and illustration, and then glued on cardboard together with the source specimens. The abbreviations "BL", "BW", "EL", "EW", "PL", and "PW" are employed for "body length", "body width", "elytral length", "elytral width", "pronotal width", and "pronotal width", respectively. Body length is the sum of pronotal and elytral lengths (BL $=P L+E L)$, while body width is the greatest distance across the elytra or twice the width of an elytron $(\mathrm{BW}=2 \mathrm{EW})$. "T\#" and "S\#" refer to the \#th tergite/sternite of the abdomen, respectively (the last abdominal tergite is T8). The term "ventrite" is used for visible abdominal sternite, the first ventrite is the $2^{\text {nd }}$ sternite in true segmentation [V1 = S2]; "aedeagal sheath" is composed of a syntergite (T9+10) and the ninth sternite [S9, counted as a ventrite (V8) since it is exposed externally]; "/" separates data from separate labels in the sections of material examined.

\section{Systematics}

\section{Genus Vesta Laporte de Castelnau}

Vesta Laporte de Castelnau, 1833: 133. Type species: Vesta chevrolatii Laporte de Castelnau, 1833, monobasic. [Java]. Motschulsky, 1853a: 42; Lacordaire, 1857: 316 (synonymy with Ethra Laporte de Castelnau); Gemminger and Harold, 1869: 1638 (synonymy with Aethra Aggasiz, an unjustified emendation of Ethra); Gorham, 1880: 13 (limited to Asian species); Gorham, 1882: 102 (diagnosis); Gorham, 1887: 29 (in Lucidotinae); Olivier, 1885: 334 (in Lucidotinae); Olivier, 1888: 43 (key to Asian species); Olivier, 1907: 16 (in Lamprocerinae, including many South American species); Olivier, 1910a: 13 (catalogue); Olivier, 1911b: 55 (key to some Asian species); Winkler, 1924 1932: 491 (in Lamprocerinae); Okada, 1931: 142; Wu, 1937: 377 (in Lamprocerinae, Chinese species); Green, 1959: 93; McDermott, 1964: 37 (in Lampyrinae, Amydetini, Vestina); 1966: 79 (in Amydetinae, Vestini, catalog); 
Nakane, 1991: 8 (in Lampyrinae); Lawrence and Newton, 1995: 859 (in Amydetinae); Lai et al. 1998: 213 (in Lampyrinae, Taiwanese species); Branham and Wenzel, 2001: 567 (phylogeny of Lampyridae, collapse of Lampyrinae, Amydetinae, and Lamprocerinae); Branham and Wenzel, 2003: 5 (evolution of bioluminescence in Lampyridae); Li et al., 2006: 821 (molecular phylogeny of represented Asian genera, showing affinity with Lamprigera Motschulsky).

Cratolampis Motschulsky, 1853a: 43. Type species: Cratolampis flavicollis Motschulsky, 1853a, originally designated. [Java, erroneously cited as Philippines by McDermott (1966)]. Motschulsky, 1853b: 43; Gemminger and Harold, 1869: 1654; Fairmaire, 1891: 15 (synonymy with Vesta); Olivier, 1907: 24 (synonymy with Lucernuta Laporte de Castelnau sensu Olivier); Olivier, 1910a: 13 (synonymy with Vesta); McDermott, 1966: 80 (synonymy with Vesta).

MORPHOLOGY (based on Asian species): Medium to large, 8-20 $\mathrm{mm}$ in total length. Where known, both sexes alate and similar to each other. Head fully covered by pronotum when retracted, hypognathous; compound eyes moderate in size, with posterior margin somewhat straight, widely separated from each other; vertex to fastiginum more or less flat, smoothly transitioning; frons slightly protruding forward, narrow; antennal sockets large, with sharp antennifer in inner lateral margin of sockets; antennae 11-articled, about one-third to one-half body length in male and shorter in female, unipectinate or serrate in antennomeres 3-10 in male, branches broad at base, occupying whole respective articles, without clear differentiation between stem and branch; branches thick and flat, 1-2.5 times as long as their respective antennal articles when pectinate; antennae serrate in female; third antennal article ( = first flagellar article) always about as long as first antennal article (= scape), longer than second antennal article (= pedicel); mandibles well developed, strongly curved and pointed apically; terminal maxillary palpomere dilated, with opening on inner margin; terminal labial palpomere compressed and subtriangular; gena behind compound eyes exposed and subgena barely visible. Pronotum transversely semielliptic, with more or less prominent hind angles; surface punctate and pubescent throughout; opaque throughout or translucent on apical and lateral margins; central disc distinctly convex, with longitudinal, median sulcus either clearly or weakly expressed; lateral explanate margins broad. Pronotal pleurite elongate, with ventral margin slightly emarginate or bisinuate. Elytra elongate, subparallel-sided or slightly oval, fully covering abdomen in length, usually with three noticeable carinae on disc, occasionally four; marginal costa nearly reaching elytral base, only very base of humeri barely visible ventrally; epipleuron at humeral area moderately folded, broad in basal one-fifth and narrowly extended to apex; lateral explanate margins moderate in width. Legs slender and long; tibia straight, apical spurs present, spur formula 2-2-2; first tarsomere elongate, subequal in length with fourth tarsomere, always longer than second and third tarsomeres which are about same length; fourth tarsomere lobed, widely open dorsally; pretarsal claws simple. Pleurosternal suture of mesothorax clear. Males with eight ventrites (including exposed sternite of aedeagal sheath) and females with seven, both ventrites and tergites strongly lobed, with more or less sharp posterolateral angles; tergite as broad as or broader than corresponding ventrites; V2-6 each with a visible pair of sublateral impressions for muscle attachment; spiracles on dorsal folded portion of sternites, not visible ventrally; a pair of dotted photogenic organs 
occurring on V7; V7 with a slender, finger-like projection along central apex in male, broadly rounded and notched along central apex in female. Aedeagal sheath elongate, asymmetric, with syntergite shorter than sternite. Male genitalia modified and trilobed; parameres fused at dorsal base, more or less hooked at apices, and each with a slender and elongate, subapical extension; median lobe well sclerotized dorsally and laterally, usually robust, with a largely membranous, partially and weakly sclerotized ventral sac; basal piece broadly U- or V-shaped, about one-third total length of genitalia.

DIAGNOSIS: Most of the Vesta species have pectinate antennae which are more significant in males than in females. Species of Ledocas Olivier (s. str.) from the Neotropical region resemble Vesta but have abbreviated antennomeres and very long antennal branches. Among the Oriental fauna, Lucidina Gorham shares a very similar appearance with Vesta. Usually the antennae of Lucidina species are compressed and serrate, either strongly or weakly. Some Lucidina species also have pectinate antennae but their male genitalia never have a pair of slender appendages on the apices of the parameres as in Vesta. Some Vesta species, especially those with serrate antennae, were sometimes misidentified as Pyrocoelia. The latter genus has V7 of the males more or less rounded apically and lacks a finger-like, apical projection on $\mathrm{V7}$, and its females have shortened or rudimentary elytra.

SUBFAMILIAL ASSIGNMENT: The genus was placed in Lucidotinae by Gorham (1897), in Lamprocerinae by Olivier (1907), in Amydetinae by McDermott (1966), and in Lampyrinae by Nakane (1991). Each assignment has several proponents (vide supra). Li et al. (2006) demonstrated an affinity between Vesta and Lamprigera Motschulsky in their 50\% majority consensus tree based on sequences of mitochondrial $16 \mathrm{~S}$ ribosomal DNA for representative Asian species. A definitive placement of the genus remains undetermined but is likely closely related with Lucidota LeConte - Lucidina Gorham as evidenced by adult morphology.

DIVERSITY: Presently there are 21 species documented from Asia and 10 from Central and South America.

Key to Species of Vesta from Taiwan

1. Abdomen ventrites 1-6 dark brown to black (Figs. 2, 5, 8) (Taiwan)

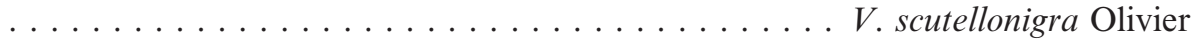

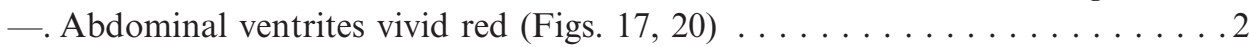

2. Antennae pectinate in male (Fig. 22) and serrate in female (Fig. 23); scutellum red; elytra subparallel-sided; body length 16-19 mm (China, Taiwan, Vietnam) . . . . . . . . . . . . . impressicollis Fairmaire

-. Antennae serrate in both sexes (Figs. 28-29); scutellum black; elytra elongate oval; body length $12-15 \mathrm{~mm}$ (China, Taiwan). . . . . . . . . . . ....................... rufiventris (Motschulsky)

\section{Vesta scutellonigra Olivier}

(Figs. 1-15)

Vesta chevrolatii Laporte de Castelnau, 1833: 133 [Type locality: Java, Indonesia], in partim. Motschulsky, 1853a: 43; Motschulsky, 1853b: 43; Gorham, 1880: 13; McDermott, 1964: 37.

Ethra chevrolatii (Laporte de Castelnau); Lacordaire, 1857: 317, in partim. 

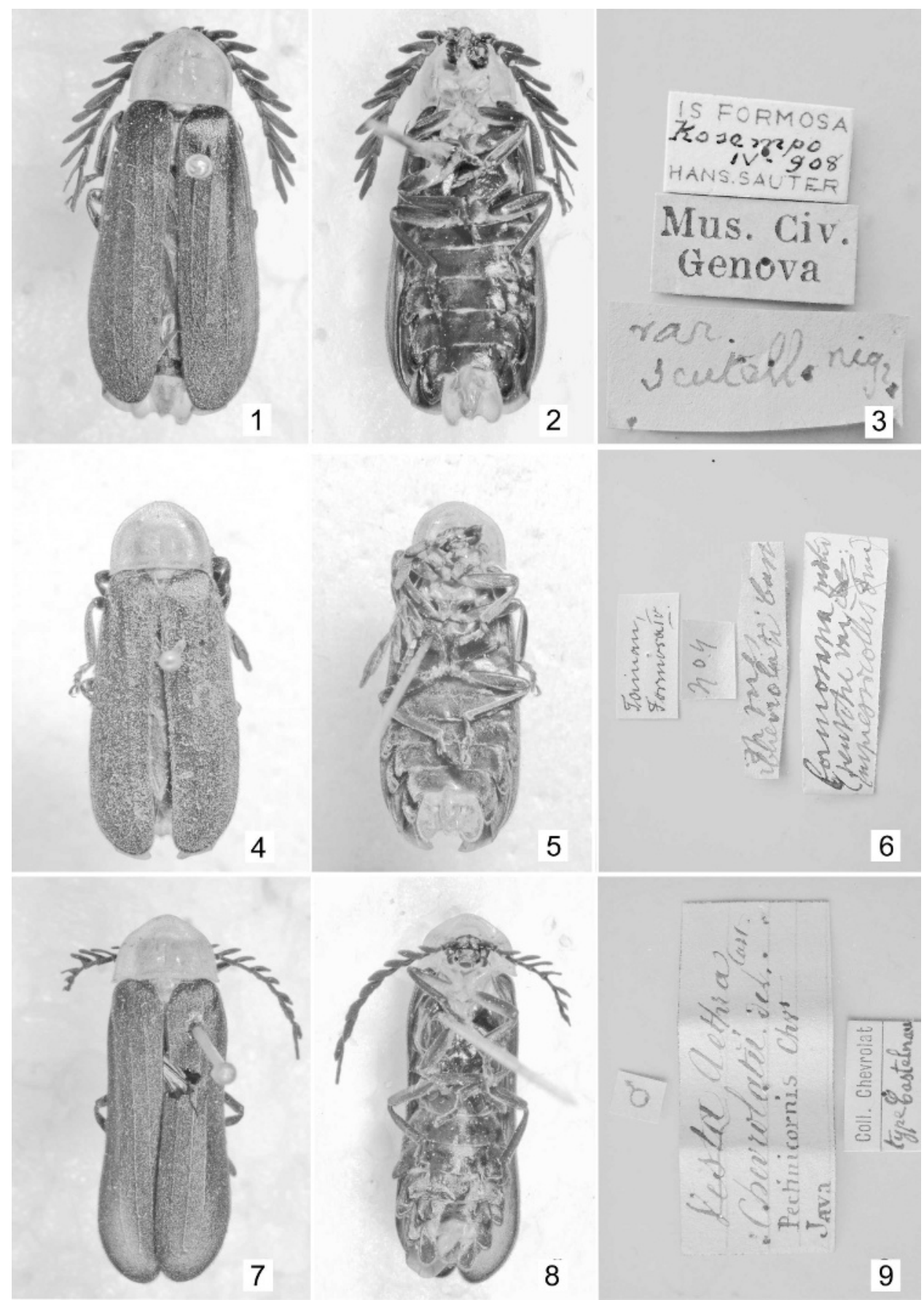

5
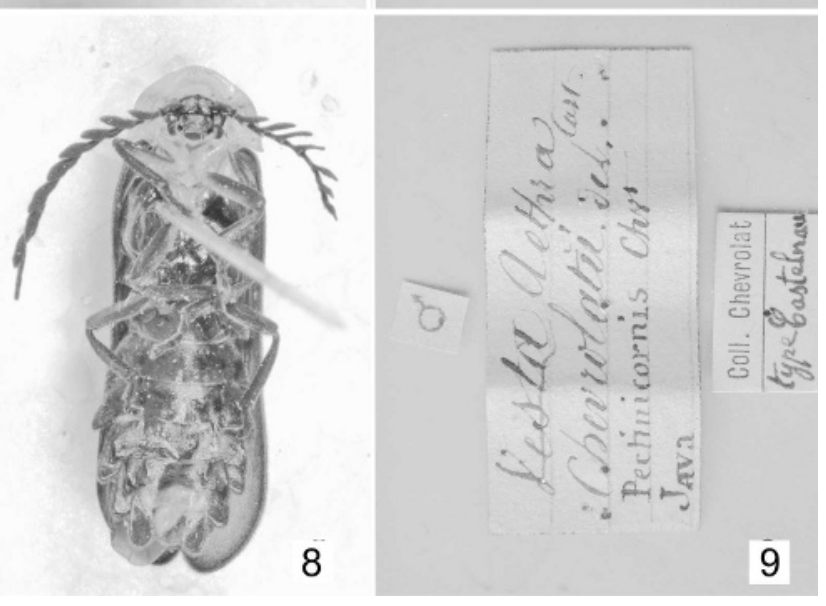

Figs. 1-9. Type specimens of some Vesta species. 1-3) Vesta scutellonigra Olivier [originally as $V$. chevrolati var. scutello nigro], lectotype male and labels; 4-6) V. formosana Pic (= V. scutellonigra), lectotype male and labels; 7-9) V. chevrolatii Laporte de Castelnau, lectotype male and labels. 

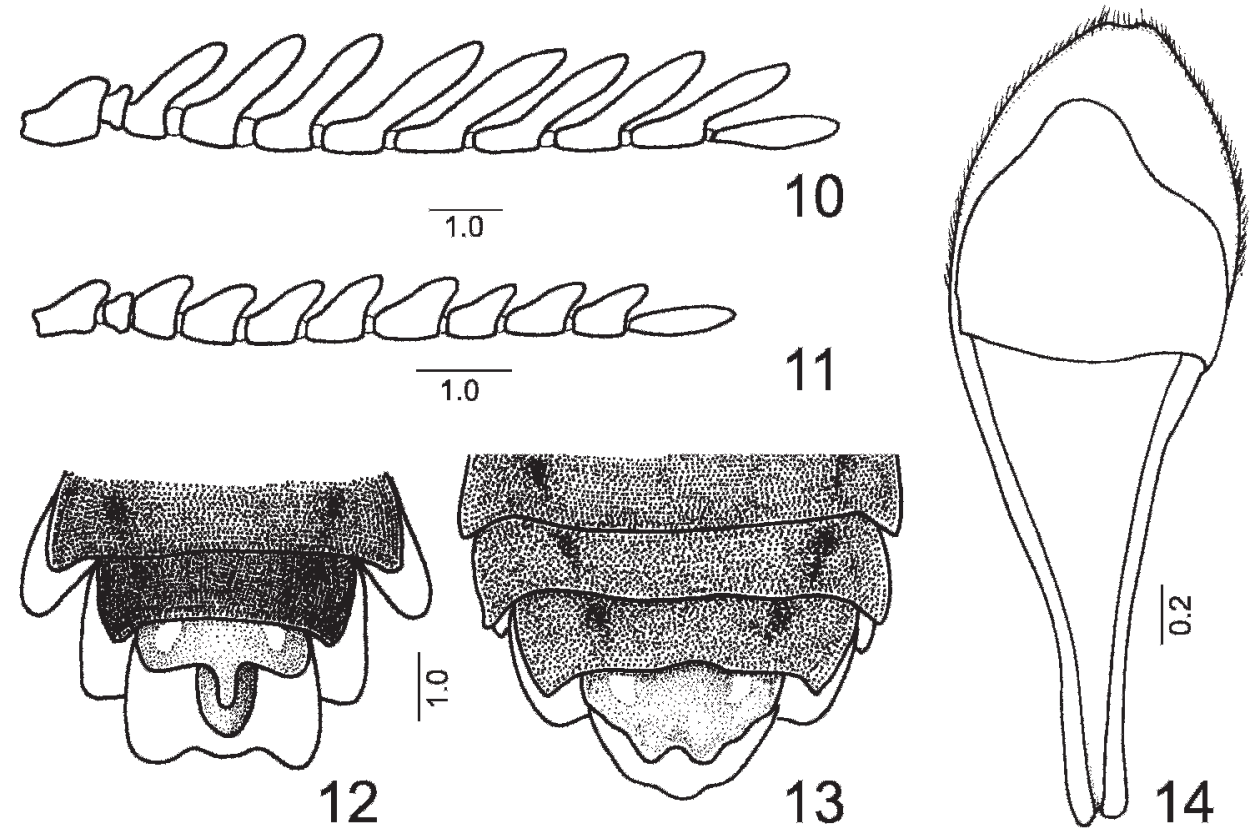

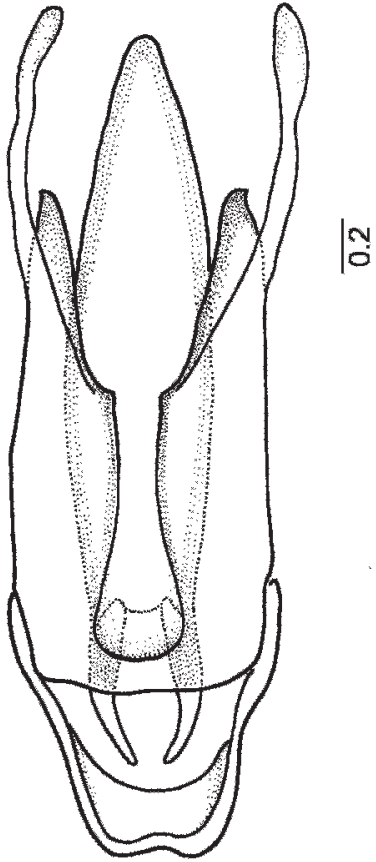

15A

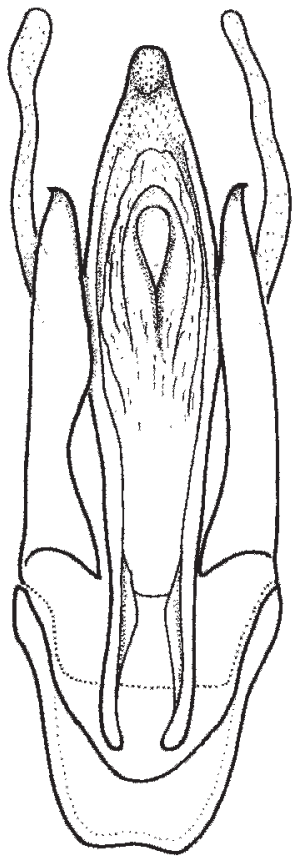

15B

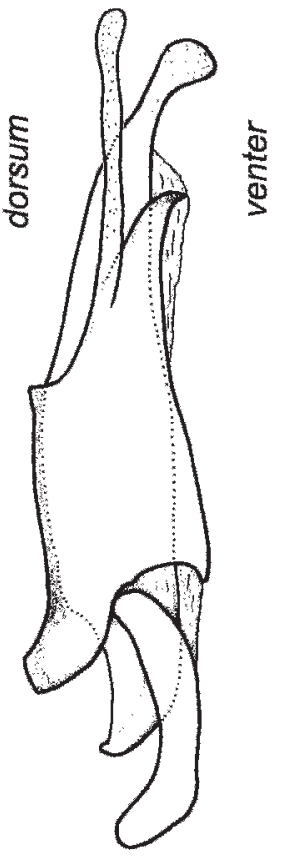

$15 \mathrm{C}$

Figs. 10-15. Vesta scutellonigra Olivier. 10) antenna, male; 11) ditto, female; 12) 6th-9th abdominal segments (tergites 6 th-8th and sternites 6 th -9 th $=$ ventrites 5 th-8th), male, ventral view; 13) 5th-8th abdominal segments, female, ventral aspect; 14) aedeagal sheath, dorsal view; 15) male genitalia, dorsal (A), ventral (B), and lateral (C) aspects. Figs. 12-13 and 15A-C each in same scale; unit of scale bars $=\mathrm{mm}$. 
Aethra chevrolati Gemminger and Harold, 1869: 1638 [incorrect subsequent spelling, unavailable], in partim.

Vesta chevrolati Olivier, 1885: 334 [incorrect subsequent spelling, unavailable]; Olivier, 1888: 43; Olivier, 1907: 17; Olivier, 1910a: 13; 1911a: 145; Okada, 1931: 135; Miwa, 1931: 99; McDermott, 1966: 79-80; Lai et al. 1998: 214 (checklist); Jeng et al., 1999a: 77 (distribution).

Vesta chevrolati var. scutello nigro Olivier, 1913: 269 [Type locality: Jiashien (= Kosempo), Kaohsiung County, southern Taiwan]. Automatically emended to scutellonigro as original spelling (ICZN, 1999: Arts. 11.9.5, 32.5.2.3) and further emended to scutellonigra so that its gender agrees with that of Vesta (ICZN, 1999: Art. 31.2).

Vesta scutellonigra Okada, 1931: 136. New synonymy.

Vesta scutellonigro Okada, 1931: 142 [incorrect subsequent spelling, unavailable].

Vesta formosana Pic, 1944: 2 [Type locality: Tainan, Taiwan]. McDermott, 1966: 80;

Lai et al., 1998: 214. New synonymy.

DIAGNOSIS: BL 16-19 mm, BW 5.4-6.3 mm; body elongate and depressed. Coloration black, prothorax and mesosternum vividly red, last two ventrites and T8 yellowish brown (Figs. 12-13). Antenna of male pectinate (Fig. 10), with branches broad and about 1.2-2 times as long as their respective antennomeres; terminal antennomere about as long as preceding branch. Elytra elongate, each with four noticeable carinae. Abdominal tergites dull laterally; V7 with a slender projection. $\mathrm{PW} / \mathrm{PL}=1.2-1.4 ; \mathrm{EL} / \mathrm{EW}=1.9-2.2 ; \mathrm{EL} / \mathrm{PL}=3.5-4.2$. Aedeagal sheath (Fig. 14) about $2.6 \mathrm{~mm}$ long, twisted toward left, with its sternite narrow at base. Male genitalia (Fig. 15) about 2.5-2.6 mm long; median lobe tapering toward apex from basal half, more or less slender in apical eighth in lateral aspect (Fig. 15C); paramere shortly hooked at apex; basal piece nearly bilaterally symmetric, broadly U-shaped.

SEXUAL DIMORPHISM: Females slightly larger than males; antennae strongly serrate (Fig. 11); abdomen dilated (Fig. 13); T8 with central lobe longer than lateral ones.

TYPE MATERIAL EXAMINED: 1 syntype of $V$. scutellonigra (vide Remarks, infra): $\hat{0}$, "IS FORMOSA, Kosempo, IV-1908, HANS. SAUTER/var. scutello nigro/Mus. Civ. Genova" (MNHN, here designated as lectotype: Figs. 1-3). 1 syntype of $V$. formosana: ô, "Tainan, Formosa IV/307/sp. pres Chevrolati Cast./formosana mihi (peut etre var.: impressicollis Fairm." (MNHN, here designated as lectotype: Figs. 46); 1 syntype of $V$. chevrolatii (Figs. 7-9): " $\mathbf{\sigma} /$ Vesta Aethra Cast., Chevrolatii Ich, Pecticornis Chvr.(?) JAva/Coll. Chevrolat, type Castelnau"' (MNHN).

material examined: Taiwan. Kaohsiung Co.: 20ิ, Liugui, 3.III.1978, K. Matsuda;

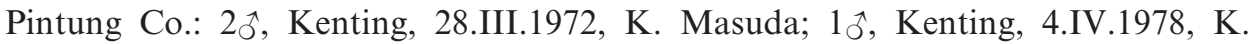

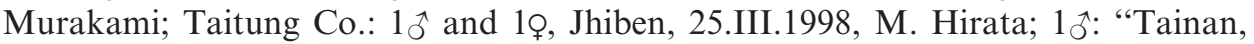
Formosa IV/307/Vesta chevrolati Cast (div vid) (var. scutello et femular nigris)" (MNHN).

REMARKS: Olivier (1911a) recorded $V$. chevrolatii (as chevrolati in his description, vide infra) from Taiwan and later described it as a variety under the name "scutello nigro" (Olivier, 1913). These two words together refer to a single entity (i.e., black scutellum) and are therefore admissible as a species-group name when they are united into a single word (ICZN, 1999: Arts. 11.9.5, 32.5.2.3). Okada (1931) adopted Olivier's concept and described the Taiwanese population as a distinct species for which he simultaneously used the names $V$. scutellonigra and $V$. scutellonigro in the 
same paper. Okada (1931) attributed authorship for these taxa to himself thereby indicating that he intended them to be new relative to the name proposed by Olivier (1913). Accordingly, these names are herein treated as synonyms rather than emendations. Under the Principle of First Reviser (ICZN, 1999: Art. 23) we adopt scutellonigra as the valid name for Okada's taxon as this spelling appears twice in his article, while scutellonigro appears only once. Vesta scutellonigra Okada is accordingly a junior synonym, and simultaneously a junior homonym, of $V$. scutellonigra Olivier while scutellonigro becomes an incorrect subsequent spelling and thereby unavailable. Okada did not designate a type series but referred his taxon to the original series of Olivier (1913). The type series is therefore identical to Olivier's original designation (ICZN, 1999: Art. 72.4.4). While the name may appear malformed in Latin, it cannot be altered as incorrect Latinization does not constitute a case by which a name may be emended (ICZN, 1999: Art. 32.3).

Vesta formosasa Pic is without doubt a new synonym of $V$. scutellonigra. Gemminger and Harold (1869) changed the original spelling of chevrolatii to chevrolati which was subsequently cited by several authors (vide supra). Though the latter has been more frequently used than the former since then, it does not match the requirements of a prevailing usage to be preserved as the correct original spelling (ICZN, 1999: Arts. 23.9.1, 33.3.1). Accordingly chevrolati is an incorrect subsequent spelling and unavailable (ICZN, 1999: Art. 33.4).

We accept Okada's conclusion and consider $V$. scutellonigra as a species distinct from $V$. chevrolatii rather than as a subspecies of the latter. In support of this decision we cite the following differences between males of $V$. scutellonigra and of $V$. chevrolatii: 1) scutellum is red in $V$. chevrolatii and black in scutellonigra, as the specific epithet denotes; 2) abdominal T8 black or dark brown in $V$. chevrolatii but yellowish brown in $V$. scutellonigra; 3 ) antennal branches are narrow and tapering toward apex in $V$. chevrolatii, broad and somewhat rounded apically in $V$. scutellonigra; 4) pro- and mesofemora black in $V$. scutellonigra but yellowish brown in $V$. chevrolatii; 5) median lobe of aedeagus is more slender and acute in apical third in $V$. chevrolatii by comparison with $V$. scutellonigra.

DISTRIBUTION: Southern and southeastern Taiwan.

PHENOLOGY: Adults are active from February to April.

\section{Vesta impressicollis Fairmaire}

(Figs. 16-18, 22-27)

Vesta impressicollis Fairmaire, 1891: 15 [Type locality: Changyang, Hubei Province, China]. Fairmaire, 1909: 247 (Guizhou Province); Olivier, 1907: 17; 1910a: 14; 1913: 269 (Taiwan); Winkler, 1924-1932: 491; Kano, 1930: 242; Miwa, 1931: 99; Okada, 1931: 142; Lai et al., 1998: 214 (checklist); Jeng et al., 1999a: 77 (distribution).

DIAGNOSIS: BL 15-20 mm, BW 5.1-6.3 mm; body elongate and compressed. Coloration vivid or pinkish red; head, antennae, legs, and elytra black, last two ventrites yellowish brown (Figs. 24-25). Antenna of male pectinate (Fig. 22), with branches slightly longer than or about as long as their respective antennomeres; last antennomere longer than preceding branch. Elytra subparallel-sided and elongate; each with 3-4 noticeable carinae in which humeral and two inner costae stronger (sutural costa not counted). Abdominal tergite sharply pointed posterolaterally; V7 with a slender projection. $\mathrm{PW} / \mathrm{PL}=1.3-1.5 ; \mathrm{EL} / \mathrm{EW}=2.1-2.4 ; \mathrm{EL} / \mathrm{PL}=4.1-4.4$. 

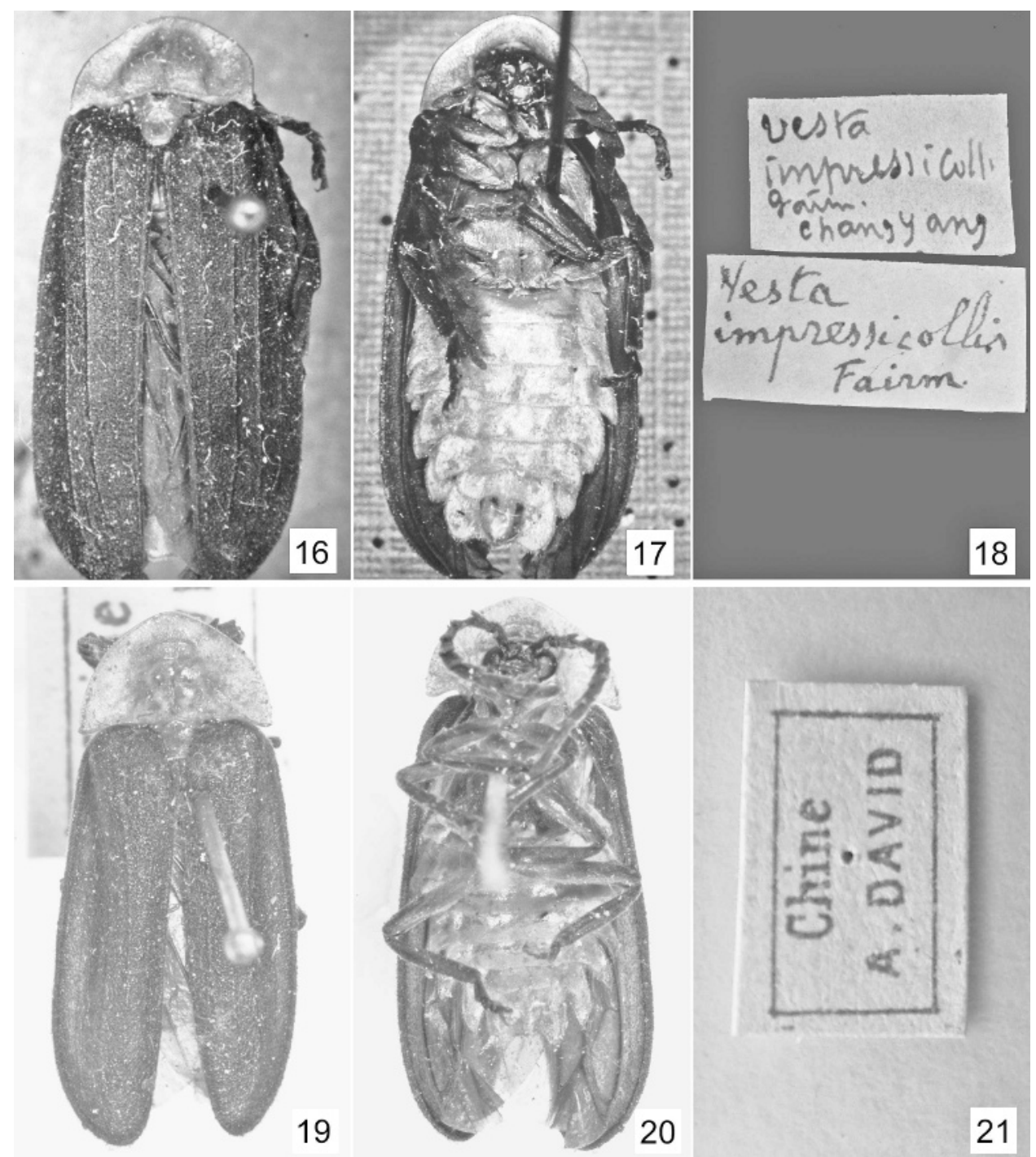

Figs. 16-21. Type material of two Vesta species. 16-18) Vesta impressicollis Fairmaire, lectotype male and labels; 19-21) Lucernuta flaviventris Fairmaire (= V. flaviventris), holotype male and label.

Aedeagal sheath (Fig. 26) 2.6-2.7 mm long, twisted toward left, broad at base of sternite. Male genitalia (Fig. 27) about 2.3-2.5 mm in length, similar to those of preceding species; median lobe broad in lateral aspect (Fig. 27C); basal piece slightly asymmetric at apex.

SEXUAL DIMORPHISM: Females slightly larger than males; antennae serrate (Fig. 23); abdomen enlarged (Fig. 25), with T8 slightly trilobed.

TYPE MATERIAL EXAMINED: Three syntypes of $V$. impressicollis: $2 \hat{\jmath}$ and 1 , one male labeled "Vesta impressicollis Fairm. Chang Yang/Vesta impressicollis Fairm." (here designated as lectotype: Figs. 16-18); the other two without labels (MNHN). 

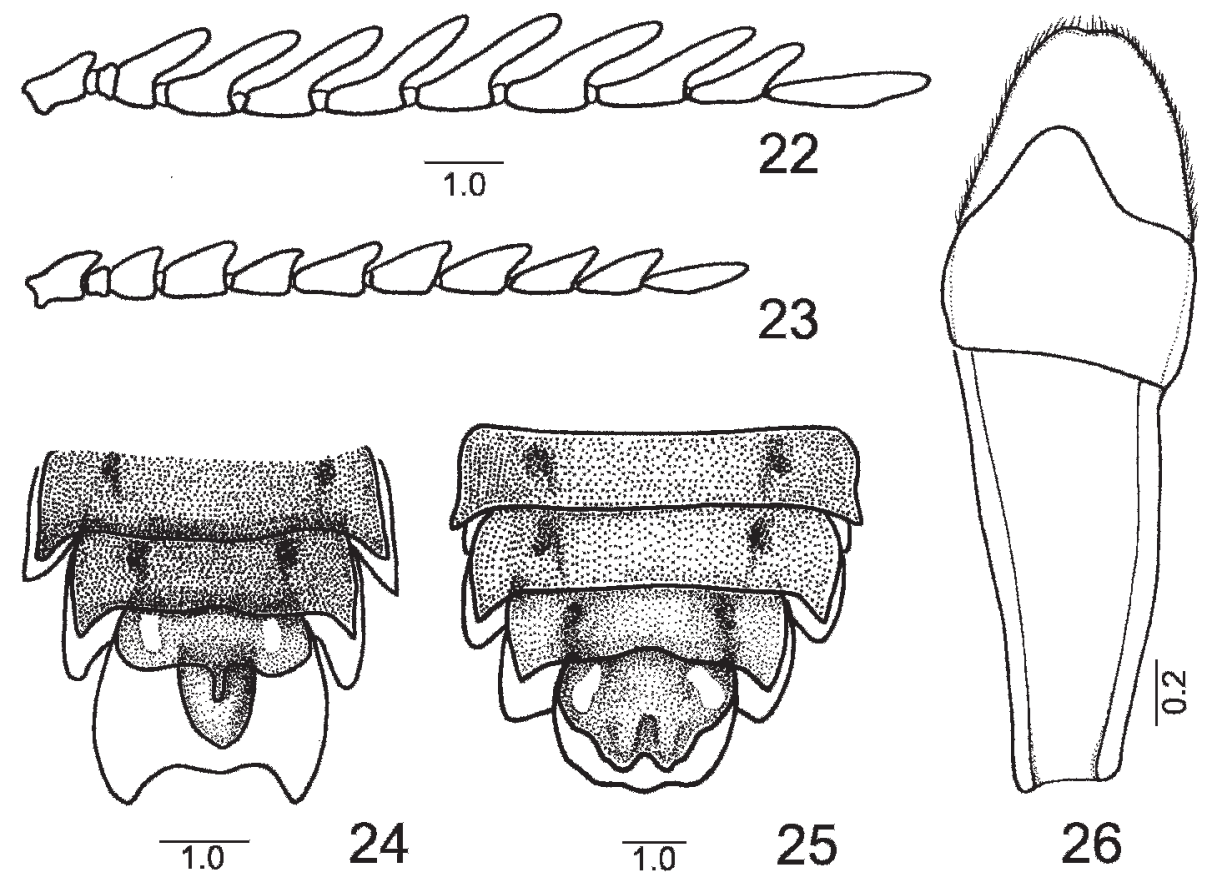

26
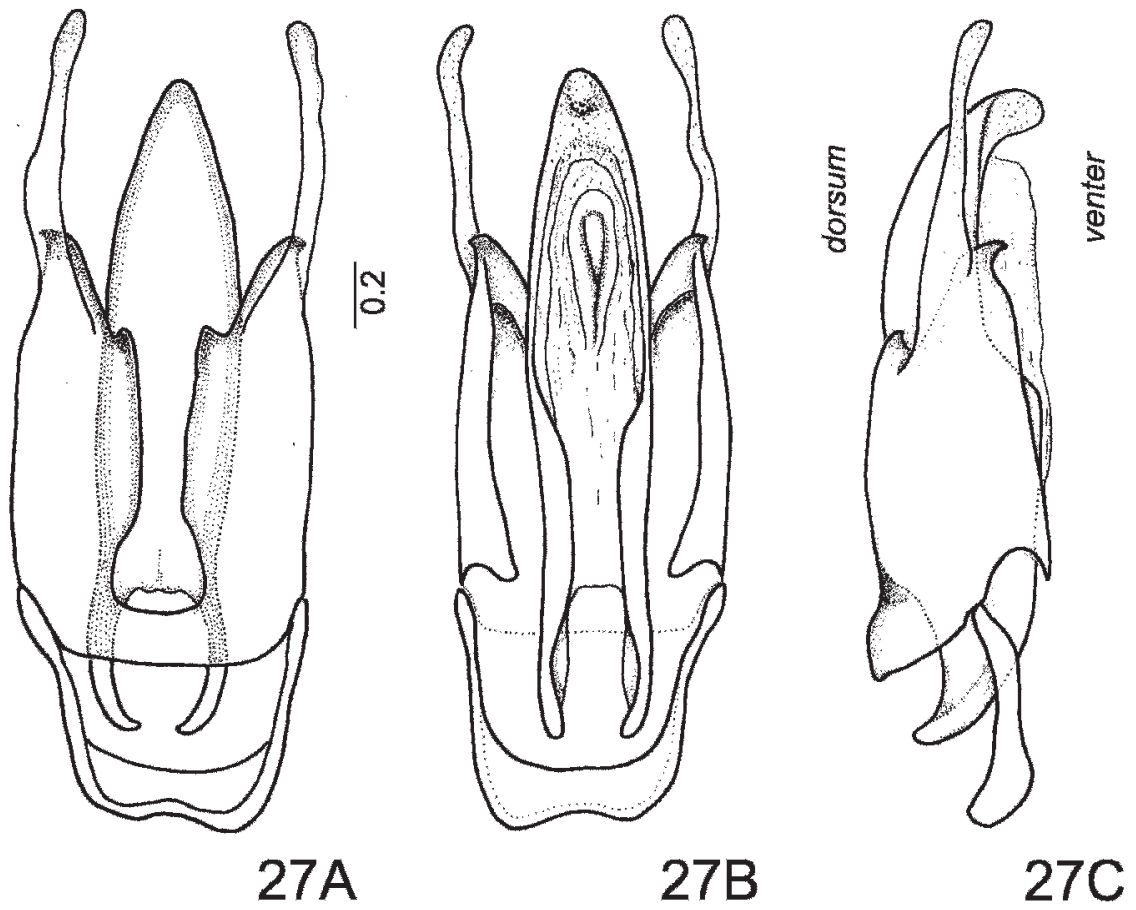

Figs. 22-27. Vesta impressicollis Fairmaire. 22) antenna, male; 23) ditto, female; 24) 6th-9th abdominal segments (tergites 6 th-8th and sternites 6 th-9th $=$ ventrites 5 th-8th), male, ventral view; 25) 5th-8th abdominal segments, female, ventral aspect; 26) aedeagal sheath, dorsal view; 27) male genitalia, dorsal (A), ventral (B), and lateral (C) aspects. Figs. 22-23 and 27A-C each in same scale; unit of scale bars $=\mathrm{mm}$. 


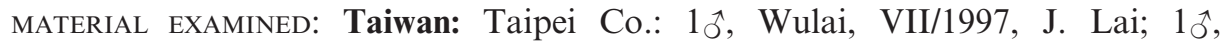
Hsindian, 18.V.1982, M.L. Chu; Taoyuan Co.: 10, Mt. Lala, 25.VI.1988, J.D. Ding; Nantou Co.: 1ð̊, Shizitou, 10-13.VI.1995, Y. Arita; 1o, Lushan, 11.V.1975, S.

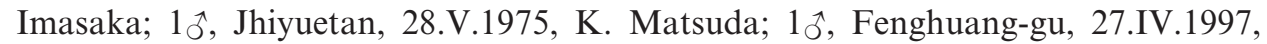

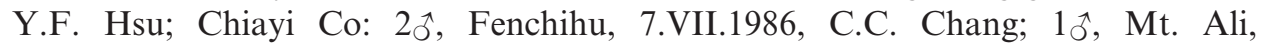
12.VII.1984, Y. Arita; Ilan Co.: 18 $\hat{0}$ and 7o, Chilan Giant Tree Park, 24.VII.2003, C.L. Li; Hwalien Co.: $15 \hat{\jmath}$ and 6o, Wangrong logging track, 9.VII.2003, M.L. Jeng; 1ðิ, Shenmigu, 22.IV.1996, M.F. Chen. China: Sichuan

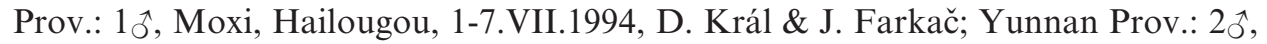
Xianguan, 18.VI.1994; J. Farkač \& D. Král; Shaanxi Prov.: 1ðૈ, Xian, Huashan, 1722.VI.1991, Z. Kayval; Fujian Prov.: 3ో人, Guadun [=Kuatun, Fukien], 8.VII.1946, C. X. Fu [= TSCHUNG SEN.].

REMARKS: We found a pair of specimens identified as Lucernuta nigroflava Fairmaire in David Oberthür's collection in MNHN. They agree well with $V$. impressicollis. However, they clearly do not match Fairmaire's (in Deyrolle and Fairmaire 1878) or Olivier's (1886) descriptions of L. nigroflava. The true $L$. nigroflava should have black abdominal ventrites except the apical three segments yellow, as the specific epithet clearly indicates. Indeed, owing to this Fairmaire (in Deyrolle and Fairmaire 1878) suspected the species capable of luminescence. Olivier (1886) stated that the type(s) of L. nigroflava was in Oberthür's collection. All of the identification labels in that box were in Fairmaire's hand, and it is possible that these specimens are types if they do, indeed, represent material upon which he based descriptions. However, as noted, these specimens do not match the descriptions provided by Deyrolle and Fairmaire (1878) nor Olivier (1886) and are not believed to represent the former's syntype series for $L$. nigroflava. The true type(s) of $L$. nigroflava was probably somewhere else and a subsequent individual perhaps misplaced these two specimens in the position for L. nigroflava in Oberthür's box. Thus, we are not able to confirm at present this strongly suspected synonymy.

DISTRIBUTION: The species occurs in both China and Taiwan, and is widely distributed in the latter except the most southern regions.

PHENOLOGY: The species is active from April to July in Taiwan.

Vesta rufiventris (Motschulsky)

(Figs. 28-33)

Cratolampis rufiventris Motschulsky, 1853b: 43 [Type locality. China]. Gemminger and Harold, 1869: 1654.

Craptolampis (Vesta) rufiventris Motschulsky; Fairmaire, 1891: 15.

Lucernuta rufiventris (Motschulsky); Olivier, 1907: 26.

Vesta rufiventris (Motschulsky); Fairmaire, 1909: 247 (Guizhou, China); Olivier, 1910a: 14; 1913: 269 (Taiwan); Winker, 1924-1932: 491; Miwa, 1931: 100; Lai et al., 1998: 214; Jeng et al., 1999a: 77; Chen, 1999: 168; 2003: 207.

Pyrocoelia rufiventris (Motschulsky); Olivier, 1911b: 56.

Vesta (Cratolampis) rufiventris (Motschulsky); Okada, 1931: 142.

Lychnuris rufiventris (Motschulsky); McDermott, 1966: 18.

DiAGNOSIs: BL 12-15 mm, BW 6.0-6.3 mm; body elongate oval and depressed. Pronotal central disc, prosternite, and abdominal ventrites 1-6 red; pronotal margins smoky brown; scutellum, elytra, and meso- and metasternites black; last two ventrites yellowish brown. Antenna of male serrate (Fig. 28). Pronotum transversely 

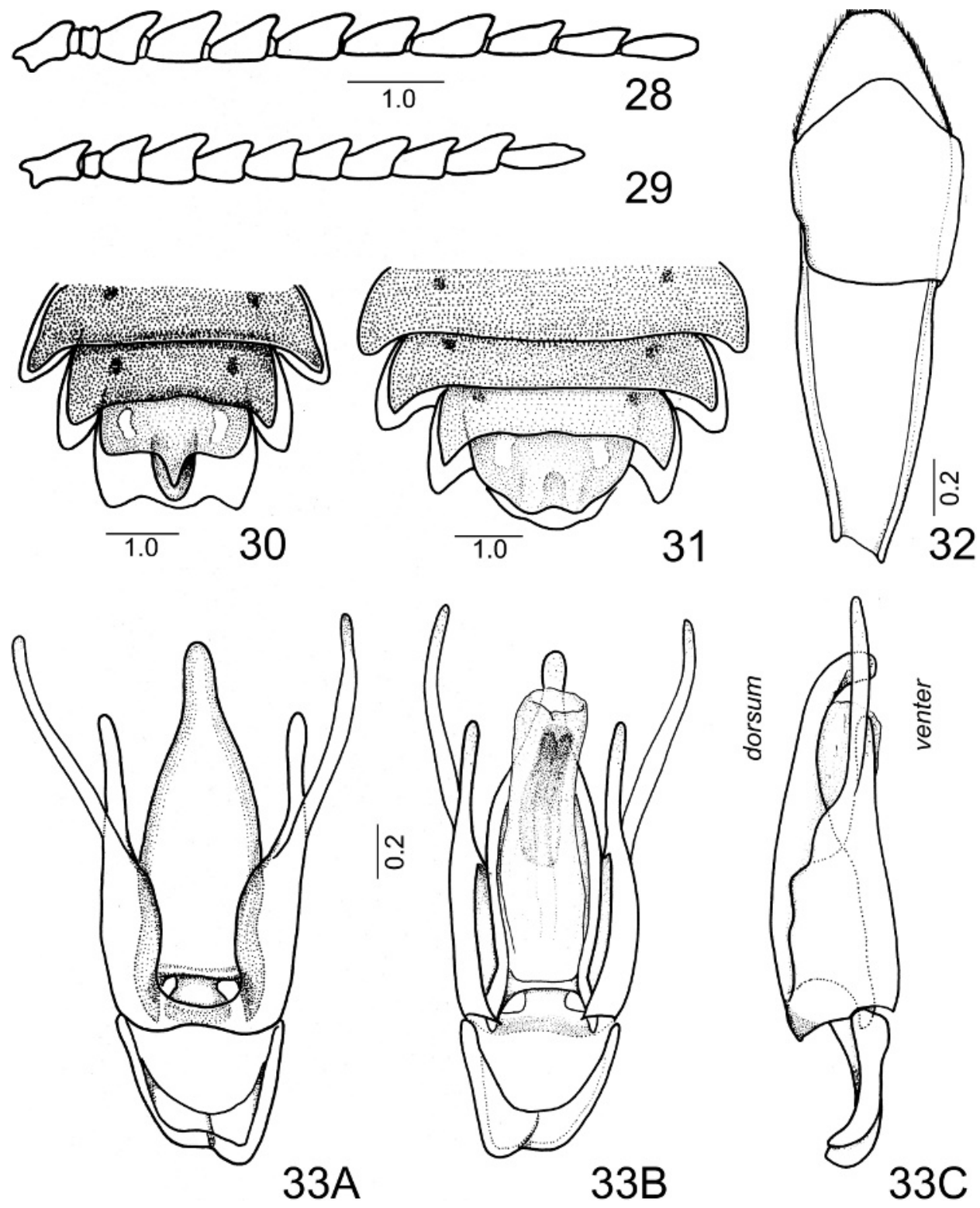

Fig. 28-33. Vesta rufiventris (Motschulsky). 28) antenna, male; 29) ditto, female; 30) 6th-9th abdominal segments (tergites 6th-8th and sternites 6th-9th $=$ ventrites 5th-8th), male, ventral view; 31) 5th-8th abdominal segments, female, ventral view; 32) aedeagal sheath, dorsal view; 33) male genitalia, dorsal (A), ventral (B), and lateral (C) aspects. Figs. 28-29 and 33A-C each in same scale; unit of scale bars $=\mathrm{mm}$.

subtriangular. Elytra elongate oval, broadest in apical third, carinae not so distinct as in preceding two species. Abdominal tergites more or less pointed posterolaterally, V7 with a triangular projection (Fig. 30). PW/PL = 1.5-1.7; EL/EW = 1.6-1.8; EL/ $\mathrm{PL}=3.3-3.5$. Aedeagal sheath (Fig. 32) about $2.2 \mathrm{~mm}$ long, twisted toward right, broad at base of sternite. Male genitalia (Fig. 33) about $2.0 \mathrm{~mm}$ in length; median 
lobe abruptly narrowed in apical seventh; paramere slender in apical third and rounded apically; inner margins smoothly curved; basal piece asymmetric.

SEXUAL DIMORPHISM: Females larger and much broader than males; antennae (Fig. 29) shorter and not as serrate as in male; abdomen (Fig. 31) greatly dilated and lobed, more or less diamond-shaped.

material eXamined: Taiwan. Taoyuan Co.: 3̧̋, Baling, 18.VII.1997, K. Mizota;

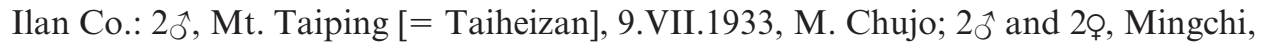
20.VII.1997, K. Mizota; 2ર̂, Chilan Giant Tree Park, VII.2003, C.L. Li. Hwalian Co.: Tungli [=Kirisato], 7.VIII.1954, R. Takahashi. China. Fujian Prov.:1 ${ }^{\widehat{\gamma}}$ and 1o, Guadun [= Fukien, Kuatun], 27.VI.1946, C.X. Fu [= Tschung-Sen, Fu]; Sichuan Prov.: 1ðै, Mt. Emai, 18.VII.1990, L. \& M. Bocak (Naturhistorisches Museum Basel, Switzerland NMB). We did not examine the types of those species that are perhaps deposited in the Zoological Museum, St. Petersburg or Moscow State University.

REMARKS: This species was described as the second Cratolampis species by Motschulsky. This genus has been synonymized with Lucernuta or Vesta by different authors (vide supra). The taxa Lucernuta, Pyrocoelia, and Lychnuris have been long confused as synonyms due to different interpretations by subsequent authors, and have only recently been clarified by Jeng et al. (1999c). This explains why rufiventris was alternately transferred among these genera during its taxonomic history. Such generic misplacements may have resulted by authors being misled by the serrate antennae. The morphology of the male genitalia of $V$. rufiventris fundamentally agrees with that of the other species of Vesta.

DISTRIBUTION: The species is distributed in Taiwan and central and southern China. Most of the recently collected specimens from Taiwan were from the northern regions, but the species was previously recorded from central and southern Taiwan by Kano (1930) and Miwa (1931). Olivier (1907) and Satô (1970) recorded the species from the Philippines. We examined Satô's material from the Philippines and found it was of $V$. flavicollis (Motschulsky) and not $V$. rufiventris. We have not examined Olivier's specimens from the Philippines.

PHENOLOGY: The species is active from June to August in Taiwan.

ADDITIONAL REMARK: We examined the type specimen of another species, Lucernuta flaviventris Fairmaire (n.comb. in Vesta), from Moupin of Sichuan Province, China (in Deyrolle and Fairmaire, 1878). The species is surely a species of Vesta and its taxonomic history mirrors that of $V$. rufiventris (vide infra). Actually, the general morphology suggests that $L$. flaviventris is likely a junior synonym of $V$. rufiventris. Both species can be found in Sichuan Province. Presently we will leave the synonymy open because we did not examine the male genitalia of $L$. flaviventris nor compare the specimen with the type of $V$. rufiventris. Despite the implication of the specific epithet, L. flaviventris has a faded pink coloration to the abdomen rather than yellow. It is not rare to see such kind of fading of coloration among Vesta specimens along ages.

\section{Vesta flaviventris (Fairmaire), new combination}

(Figs. 19-21)

Lucernuta flaviventris Fairmaire In Deyrolle and Fairmaire, 1878: 114 [Type locality: Moupin (= currently known as Baoxing County), Sichuan Province, China];

Olivier, 1907: 25; Winkler, 1924-1932: 491.

Pyrocoelia flaviventris (Fairmaire); Olivier, 1886: 197, 203. 
Lychnuris flaviventris (Fairmaire); McDermott, 1966: 15.

TYPE MATERIAL EXAMINED: Holotype of L. flaviventris, ô: "Chine, A. DAVID/ Lucernuta flaviventris F. Moupin" (MNHN, Figs. 19-21).

\section{Acknowledgements}

We are grateful to T. Deuve, J.J. Menier (NMNH), M. Brancucci (NMB), and the late Dr. M. Satô for their assistance in finding material; and to A. Polaszek (ICZN) and M.A. Jäch (Naturhistorisches Museum, Wien) for consulting on nomenclatorial issues. This is the contribution No. 3479 of the Division of Entomology, University of Kansas Natural History of Museum. The study was financially supported by the National Science Council, Republic of China, grant NSC94-2621-B002-008.

\section{Literature Cited}

Branham, M., and J. W. Wenzel. 2001. The evolution of bioluminescence in cantharoids (Coleoptera: Elateroidea). Florida Entomologist 84:565-586.

Branham, M., and J. W. Wenzel. 2003. The origin of photic behavior and the evolution of sexual communication in fireflies (Coleoptera: Lampyridae). Cladistics 19:1-22.

Chang, N.-T., Z.-C. Chen, and W.-C. Hsu. 2000. List of Lampyridae in the Nanjenshan ecological research site of Kenting National Park - Comments on comparisons of similarity. Chinese Journal of Entomology 20:57-61.

Chen, T.-R. 1999. An Ecological Guide to Taiwanese Fireflies. Field Image Publications, Taipei, Taiwan. $191 \mathrm{pp}$.

Chen, T.-R. 2003. Fireflies of Taiwan. Field Image Publications, Taipei, Taiwan. 255 pp. [In Chinese]

Chûjô, M., and M. Satô. 1970. On Japanese and Formosan species of the genus Curtos Motschulsky. Faculty Education of Kagawa University 192:59-65. [In Japanese]

Deyrolle, M. M. H., and M. L. Fairmaire. 1878. Descriptions de Coléoptères recueillis par M. l'abbé David dans la Chine centrale. Annales de la Société Entomologique de France 8:87-140.

Fairmaire, M. L. 1891. Description de Coléoptères de l'interieur de la Chine. Annales de la Société Entomologique de Belgique 35:6-89.

Fairmaire, M. L. 1909. Coléoptères Lampyrides rapportés de Koui-Tcheou, Région de Pin Fa (Chine). Bulletin du Muséum national d'Histoire Naturelle, Paris 15:247-250.

Gemminger, M., and E. von Harold. 1869. Catalogus Coleopterorum hucusque descriptorum synonymicus et systematicus, Tome 5. Monachii, London, UK. pp. 1347-1808 pp.

Gorham, H. S. 1880. Materials for a revision of the Lampyridae. Transactions of the Entomological Society of London 1880:83-112.

Gorham, H. S. 1882. New species of Lycidae, Lampyridae and Telephoridae from Sumatra. Notes Leyden Museum 4:93-109.

Gorham, H. S. 1897. Malacodermata. Biologicia Centrali-Americana, Insecta, Coleoptera, Vol. III, Part 2; $372 \mathrm{pp}$.

Green, J. W. 1959. Revision of the species of Microphotus, with an emendation of the Lampyrini (Lampyridae). The Coleopterists Bulletin 8:80-96.

Ho, J.-Z. 1997. The lantern in the dark-firefly. Taiwan Endemic Species Research Center, Nantou, Taiwan. 131 pp. [In Chinese]

Ho, J.-Z., and B.-H. Jiang. 1997. Two firefly species with aquatic larvae in Taiwan. Nature Conservation Quarterly 17:42-46. [In Chinese]

Ho, J.-Z., and R.-F. Jong. 1997. Pristolycus kanoi in crisis: morphology and behavior. Nature Conservation Quarterly 18:26-31. [In Chinese]

Ho, J.-Z., and J.-S. Chu. 2002. Map for Firefly Watching in Taiwan. Morning Star Publication, Taichung City, Taiwan. 325 pp. [In Chinese]

Ho, J.-Z., T.-H. Su, and P.-S. Yang. 1998a. Notes on the firefly, Lamprigera yunnana (Fairmaire). Nature Conservation Quarterly 21:34-39. [In Chinese]

Ho, J.-Z., J.-S. Chu, and J.-C. Chu. 1998b. Discovery of the aquatic larvae of Luciola substriata. Nature Conservation Quarterly 22:47-51. [In Chinese] 
International Commission on Zoological Nomenclature [ICZN]. 1999. International Code of Zoological Nomenclature [4th Edition]. International Trust for Zoological Nomenclature, London, UK. xxix+306 pp.

Jeng, M.-L., P.-S. Yang, and M. Satô. 1998a. The genus Cyphonocerus (Coleoptera, Lampyridae) from Taiwan and Japan, with notes on the subfamily Cyphonocerinae. Elytra 26:379-398.

Jeng, M.-L., P.-S. Yang, M. Satô, J. Lai, and J.-C. Chang. 1998b. The genus Curtos (Coleoptera, Lampyridae, Luciolinae) of Taiwan and Japan. Japanese Journal of Systematic Entomology 4:331-347.

Jeng, M.-L., J. Lai, and P.-S. Yang. 1999a. A synopsis of the firefly fauna at six national parks in Taiwan (Coleoptera: Lampyridae). Chinese Journal of Entomology 19(1):65-91. [In Chinese, with English abstract]

Jeng, M.-L., P.-S. Yang, and M. Satô. 1999b. An additional new species of Cyphonocerus (Coleoptera: Lampyridae: Psilocladinae) from Taiwan. Elytra 27:405-408.

Jeng, M.-L., J. Lai, P.-S. Yang, and M. Satô. 1999c. On the validity of the generic name Pyrocoelia Gorham (Coleoptera, Lampyridae, Lampyrinae), with a review of Taiwanese species. Japanese Journal of Systematic Entomology 5:347-362.

Jeng, M.-L., J. Lai, P.-S. Yang, and M. Satô. 2000. Notes on the taxonomy of Lamprigera yunnana (Fairmaire) and the genus Lamprigera Motschulsky (Coleoptera: Lampyridae). Japanese Journal of Systematic Entomology 6:313-319.

Jeng, M.-L., J. Lai, P.-S. Yang, and M. Satô. 2001. Revision of the genus Diaphanes Motschulsky (Coleoptera, Lampyridae, Lampyrinae) of Taiwan. Japanese Journal of Systematic Entomology 7:203-235.

Jeng, M.-L., P.-S. Yang, and M. Satô. 2002. Notes on the morphology and systematics of the genus Pristolycus Gorham (Coleoptera: Lampyridae). Japanese Journal of Systematic Entomology 8:87-108.

Jeng, M.-L., P.-S. Yang, and J. Lai. 2003a. Notes on the genus Luciola (Coleoptera: Lampyridae, Luciolinae) of Taiwan. Special Bulletin of the Japanese Society of Coleopterology, Tokyo 6:247-262.

Jeng, M.-L., J. Lai, and P.-S. Yang. 2003b. Lampyridae: a review of aquatic fireflies with description of a new species. Pp. 539-562. In M. A. Jäch and L. Ji (eds.). Water Beetles of China, Vol. III. Zoologische-Botanische Gesellschaft in Osterreich and Wiener Coleopterologenverein, Vienna, Austria. vi +572 pp.

Jeng, M.-L., and P.-S. Yang. 2003c. A supplementary account to the genus Diaphanes (Coleoptera: Lampyridae) of Taiwan. Journal of the Kansas Entomological Society 76:477-483.

Kano, T. 1930. Three unrecorded Fireflies from the Japanese Empire. Kontyu 4:242-245. [In Japanese]

Lacordaire, M. T. 1857. Malacodermes. Pp. 304-341. In M. T. Lacordaire (ed.). Histoire Naturelle des Insectes. Genera des Coléoptères, Vol. 2. Librairie Encyclopédique de Roret, Paris, France. 548 pp.

Lai, J., M. Satô, and P.-S. Yang. 1998. Checklist of Lampyridae of Taiwan - Coleoptera: Polyphaga: Lampyridae. Chinese Journal of Entomology 18:207-215.

Laporte de Castelnau, M. F. L. 1833. D’une révision du genre Lampyre. Annales de la Société Entomologique de France 2:122-153.

Lawrence, J. F., and A. F. Newton, Jr. 1995. Families and subfamilies of Coleoptera (with selected genera, notes, references and data on family-group names). Pp. 779-1092. In J. Pakaluk and S. A. Ślipiński (eds.). Biology, Phylogeny, and Classification of Coleoptera: Papers Celebrating the 80th Birthday of Roy A. Crowson, Vol. 2. Muzeum i Instytut Zoologii PAN, Warsaw, Poland. vi + 560-1092 pp.

Li, X., S. Yang, M. Xie, and X. Liang. 2006. Phylogeny of fireflies, Coleoptera, Lampyridae, inferred from mitochondrial 16S ribosomal DNA with reference to morphological and ethological traits. Progress in Natural Science 16(8):817-826.

Matsumura, M. 1918. The fireflies of Japan. Kyoiku-Gaho (Education Illustration Post) 6(3):82-89.

Matsumura, M. 1928. The fireflies. Pp. 39-70. In Interesting insects as education material. Toyodo Shoten, Tokyo, Japan. 326 pp.+ 18 pls.

McDermott, F. A. 1964. The taxonomy of the Lampyridae (Coleoptera). Transactions of the American Entomological Society 90:1-72.

McDermott, F. A. 1966. Lampyridae. In W. O. Steel (ed.). Coleopterorum Catalogus Supplementa, pars 9 (editio secunda). W. Junk, s-Gravenhage, Netherland. 149 pp.

Miwa, Y. 1931. Lampyridae. Pp. 99-102. In Y. Miwa (ed.). A Systematic Catalogue of Formosan Coleoptera: Report of the Department of Agriculture, Governmental Research Institute of Formosa, No. 55. Research Institute of Formosa, Taihoku [= Taipei], Taiwan. xi +359 pp. 
Motschulsky, V. 1853a. Lampyrides. Études Entomologiques 1:3-58.

Motschulsky, V. 1853b. Lampyrides (continuation). Études Entomologiques 2:33-43.

Nakane, T. 1967a. On the genus Cyphonocerus Kiesenwetter in Japan and Formosa (Coleoptera: Lampyridae). Bulletin of the National Science Museum, Tokyo 10(1):7-9.

Nakane, T. 1967b. Description of three new species of lycid-beetles from Formosa, with notes on some others (Insecta, Coleoptera). Bulletin of the National Science Museum, Tokyo 10(3):284-289.

Nakane, T. 1977. New or little-known Coleoptera from Japan and its adjacent regions. Fragmenta Coleoptera 22/24:88-96.

Nakane, T. 1991. Lampyrid insects of the world. Pp. 3-11. In The Association of Nature Restoration of Japan (ed.). The Reconstruction of Firefly Environments. Reconquista SP. No. 1. Siedeku, Tokyo, Japan. 136 pp. [In Japanese]

Okada, Y. 1931. On the scientific names of fireflies of Japan. Zoological Magazine 43:130-149. [In Japanese]

Olivier, E. 1885. Catalogue des Lampyrides. Annali del Museo Civico di Storia Naturale di Genova 22:333-374.

Olivier, E. 1886. Révision du genre Pyrocoelia Gorham (Ordre des Coléoptères; Famille des Lampyridae. Notes from the Leyden Museum 8:195-208.

Olivier, E. 1888. Études sur les Lampyrides, III, les Genera à antennes flabellées 2e partie. Annales de la Société Entomologique de France 8:35-62.

Olivier, E. 1907. Coleoptera. Fam. Lampyridae. Pp. 1-74. In P. Wytsman (ed.). Genera Insectorum: Fascicle 53. Verteneuil and Desmet, Brussels, Belgium. 74 pp.

Olivier, E. 1910a. Lampyridae. Pp. 1-68. In S. Schenkling (ed.). Coleopterorum Catalogus: Pars 9. W. Junk, Berlin, Germany. 68 pp.

Olivier, E. 1910b. Description de Lampyrides nouves (Col.). Bulletin de la Société Entomologique de France 15:285-287.

Olivier, E. 1911a. Lampyridae rapports de Formose par M. Hans Sauter. Annali del Museo Civico di Storia Naturale di Genova 45:145-148.

Olivier, E. 1911b. Révision de Lampyrides. Revue Scientifique du Bourbonnais et du Centre de la France 24:39-58.

Olivier, E. 1913. H. Sauter's Formosa-Ausbeute, Lampyridae (Col.). Entomologische Mitteilungen 2:269-272.

Pic, M. 1911a. H. Sauter's Formosa-Ausbeute: Cantharidae, Lampyridae, Mordellidae (Col.). Deutsche Entomologische National-Bibliothek 2:188-189.

Pic, M. 1911b. Sur quelques Ototreta E. Oliver. Revue Scientifique du Bourbonnais et du Centre de la France 1911:35-36.

Pic, M. 1911c. Coléoptères exotiques nouveaux ou peu connus. L'Echange 27:142-144.

Pic, M. 1916. Diagnoses génériques et spécifiques. Mélanges exotico-Entomologiques 18:2-20.

Pic, M. 1917. Diagnoses génériques et spécifiques. Mélanges exotico-Entomologiques 22:2-20.

Pic, M. 1918. Diagnoses génériques et spécifiques. Mélanges exotico-Entomologiques 23:1-24.

Pic, M. 1944. Diagnoses génériques et spécifiques. Opuscula martialia 12:1-16.

Satô, M. 1970. Notes on the genus Cyphonocerus Kiesenwetter from Formosa (Col.: Lampyridae). Bulletin of the Japan Entomological Academy 5(1):22-24.

Winkler, A. 1924-1932. Lampyridae. Pp. 491-495. In A. Winkler (ed.). Catalogus Coleopterorum Regionis Palaearcticae, Part 4. Albert Winkler, Vienna, Austria. vi + 1698 pp.

Wu, C.-F. [= Hu, J.-F.]. 1937. Family Lampyridae. Pp. 377-385. In C.-F. Wu (ed.). Catalogus Insectorum Sinensium Vol. 3. Fan Memorial Institute of Biology, Peiking [= Beijing], China. 1312 pp. 